\title{
地震と津波重畳時における 防波堤への加振周波数の影響に関する研究
}

\author{
岡田 克寛 1 - 鈴木 高二朗 2 - 有川 太郎3 \\ 1正会員 港湾空港技術研究所 海洋研究領域 而波研究グループ 研究官 \\ （干239-0826 神奈川県横須賀市長瀬3丁目1-1) \\ E-mail:okada-k88s3@pari.go.jp \\ 2正会員 波港湾空港技術研究所 海洋研究領域 而波研究グループ長 \\ （干239-0826 神奈川県横須賀市長瀬3丁目1-1） \\ E-mail:suzuki_k@pari.go.jp \\ 3 正会員 中央大学教授 理工学部 都市環境学科 \\ （一112-8551 東京都文京区春日一丁目13-27） \\ E-mail: taro.arikawa.38d@g.chuo-u.ac.jp
}

2011年3月11日に発生した，東北地方太平洋沖地震津波では，震源のマグニチュードは9.0と我が国でも 最大クラスの大きさの海溝型地震であった。この時に発生した, 津波によって多くの防波堤が被災した. 津波は，第一波来襲時から最大高さの波を確認するまでに，短いところでは数分，長いところでは何時間 もかけて津波が来襲する。その津波が防波堤を越流している時にも，余震の影響が防波堤に作用している 可能性が考えられるが，地震と津波が重盢した時に防波堤にどのような影響を与えるかが明確にはわかっ ていない, そこで, 本研究では, 地震と津波の重畳現象を再現できる大規模水路を用いて, 周波数の違い による影響と，マウンドの変形の有無による違いについて，明らかにすることを目的とした.

\section{Key Words : earthquake,tsunami,superpotision,breakewater}

\section{1. はじめに}

2011年3月11日に発生した，東北地方太平洋沖地震津 波では，震源のマグニチュードは9.0と我が国でも最大 クラスの大きさの海溝型地震であった。この地震の影響 で，津波も発生し，高いところでは9.3m以上の高さの津 波が観測された。この地震津波では，多くの構造物が被 災したが，そのほとんどが津波に起因するものと考えら れており，津波の越流に対して対策が検討され，粘り強 い構造とするべく，施工されている1)。一方で，津波は 大きな地震が発生した後に来襲するが，地震の本震の後 には数多くの余震が発生する. 津波来襲時においては, 同時に余震が発生し，防波堤の安定性に影響を与えてい る可能性が考えられる。 そこで，岡田ら 2)は地震と津波 の重畳現象について, 東北地方太平洋沖地震津波の際の 津波第一波の山・谷出現時刻から津波最大高さの発現時 刻とその間の余震発生状況を代表地点で確認し, 津波来 襲時において，余震の影響がある可能性について明らか にした. また, 地震と津波の重畳現象について, 水理模 型実験を行い，加速度の影響が小さい状態ではあるが， 静水圧式と westergaardの近似式了の重祆合わせにより，防 波堤に与える作用力が表現できることを明らかにした. しかし，地震と津波重畳時における，地震の周波数の違
いによる防波堤への影響については，検討されていない， 同じケーソン式構造物について地震動の周波数成分に関 して，野津ら怆よって，実スケールにおいては，2Hz以 下の振動数成分から岸壁の実変位を推定できることが確 認されており，地震と津波の重畳時においても，周波数 によって影響が異なる可能性が考えられる，そこで，本 研究は，地震と津波重畳時において，地震の周波数の違 いによって防波堤に与える影響の違いについて明らかに することを目的とした.

\section{2. 水理模型実験概要}

実験は，地震と津波の重畳現象を再現可能な大型水路 で行った．水路は長さ $184.0 \mathrm{~m}$ ，幅 $3.5 \mathrm{~m}$ ，高さ $12.0 \mathrm{~m}$ 水 路で，津波越流が再現可能な還流装置，地震の振動が再 現可能な水中振動台を備えた大型の水路である.

防波堤のモデルは，K港の防波堤をモデルとし，縮尺 1/20の断面を製作した．図-1に示寸とおり，水中振動台 の上に地盤製作用の枠を設置し，その枠内に中目砂で砂 地盤を $0.75 \mathrm{~m}$ 作製した. その上に5号砕石を用いて，マウ ンド $0.25 \mathrm{~m}$ 設置し，マウンド上に重量と重心を調整した， 高さ $1.19 \mathrm{~m}$ ，幅 $0.74 \mathrm{~m}$ のコンクリート製のパラペット構造 を有した防波堤模型を設置した。 
図-2はケーソンに設置した加速度計，波圧計，変位計 の設置状況である。防波堤模型には，前面に波圧計 (PG : エスエスケイ製，P310V-02S)を設置した。また， 模型底面と天端からそれぞれ $10 \mathrm{~cm} の$ 位置とマウンド内 に加速度計(AC : 共和電業製, ASW-2A)を設置した。模 型の変位を計測するため, 底面から $10 \mathrm{~cm}$ とパラペット 天端から $10 \mathrm{~cm} の$ 箇所にワイヤー式の変位計(DT : 共和電 業製，DTP-D-5KS-P)を設置し，計測した。

初期水位は，模型パラペット天端上 $10 \mathrm{~cm}$ と，還流 装置を用いて，防波堤の津波越流状態を再現した。還流 装置による越流が定常状態となったことを確認した後に 加振を行い，地震と津波の重畳現象を再現した。（図-3）

実験は，地震と津波の重畳時の影響の違いを把握する ため，同様な条件で越流が無い場合の実験も行った。ま た，マウンドの変形の有無による防波堤への影響の違い を確認するため, マウンドは変形しないようセメントペ 一ストで固めたものと, 固めていないものの2種類で行

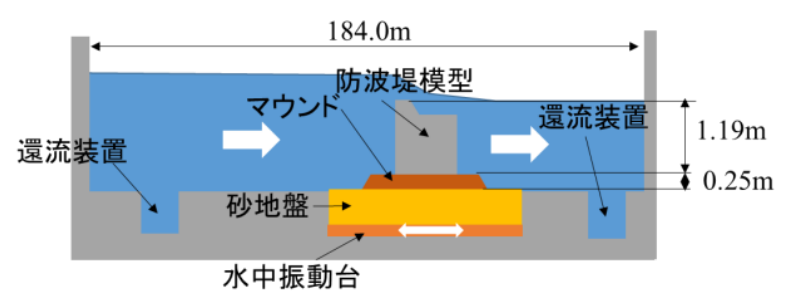

図-1 模型配置図

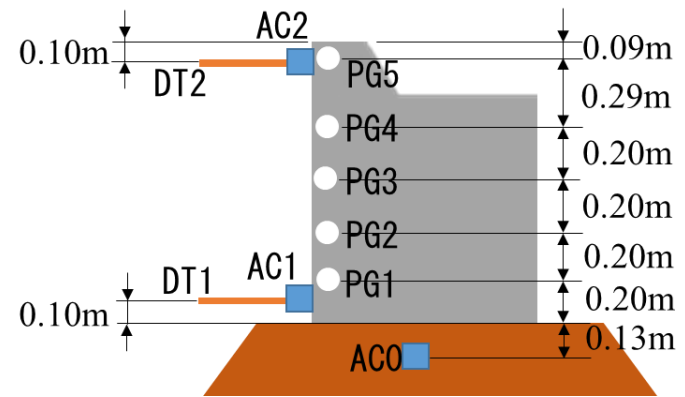

$P G$ : 波圧計 $A C$ : 加速度計 DT : 変位計

図-2 計測器配置図

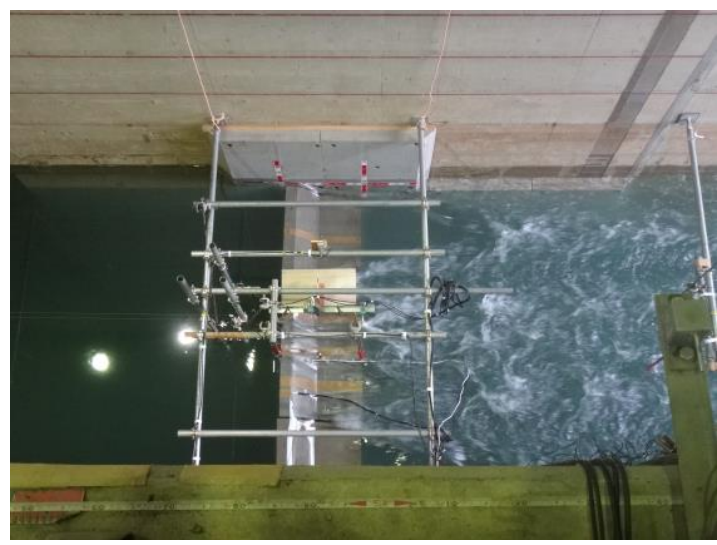

図-3 実験状況図
つた.

\section{3. 水理模型実験結果}

\section{(1) 加振周波数の違いによる防波堤への影響}

地震の周波数によって，防波堤に与える影響が異なる 事から，地震と津波の重畳時においても，どのように影 響が異なるかを確認するため，周波数を変えて，実験を 行った. 加振強度を $50 \mathrm{gal}$ ，加振周波数を $20 \mathrm{~Hz}$ 吅 $2 \mathrm{~Hz}$ ま で変えて実験を行った．例として，加速度の時刻歴につ いて, 加振周波数が $4 \mathrm{~Hz}$ と $8 \mathrm{~Hz}$ のケースについて示す. 加速度計は岸側方向が(+)で，沖側方向が(-)である. 図4(a)，（b)は8Hzにおける地震のみと，地震と津波を重畳 させたケースを示す． $8 \mathrm{~Hz}$ での模型下側加速度( $\mathrm{ACl} 1$ は, どちらも同様な挙動を示しており，地震と津波の重畳現 象の影響が小さいことがわかる。一方で，模型上側加速 度(AC2)は，模型下側加速度(AC1)同様，ほぼ同様な挙動 を示している．地震と津波が重畳したケースの方が，地 震のみのケースと比較して, 若干ピークの最大值が小さ く，ピーク值の時間がはっきりしない，これは，岡田ら 2)によって，2Hzで加震した加速度時刻歴の比較を行って いるが，その結果とと同様な傾向であることが確認でき る.また，8Hzのケースでは，模型上側加速度(AC2)と模 型下側加速度 $(\mathrm{AC} 1)$ の位相が反対になっていることが確 認できた. これは，加振周期が短く，加速度の応答が模 型上側に伝わる前に，逆向きの加速度が模型下側に作用 しているためであると考えられる.

次に，4Hzにおける地震のみと，地震と津波を重畳さ せたケースについて図-5(a)，（b)に示す．4Hzの地震の みのケースは，模型上側加速度( $\mathrm{AC} 2)$ と模型下側加速度

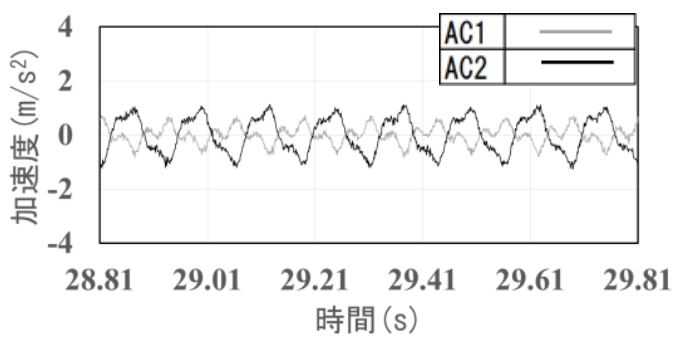

(a) $8 \mathrm{~Hz}, 50 \mathrm{gal}$, 加振のみ

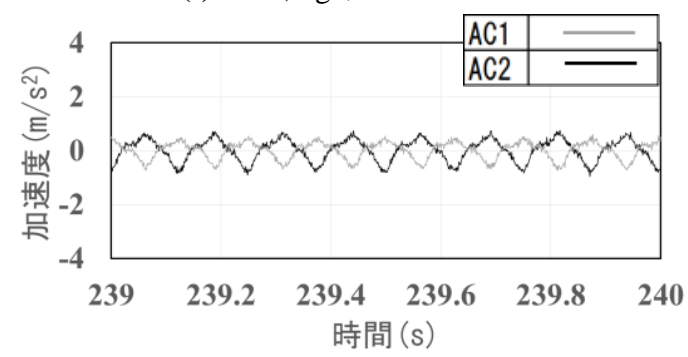

(b) $8 \mathrm{~Hz}, 50 \mathrm{gal}$, 加振と越流の重畳

図-4 加振時時刻歴(マウンド変形あり) 
(AC1)のどちらも加振周期に短周期成分がのっている状 況であった。これは，8Hzのケースと異なり，模型上側 と下側の応答のずれによって，模型下側の加速度応答が， 模型上側に作用している加速度の影響を受け，短周期成 分が現れたものであると考えられる.

一方で，4Hzにおける地震と津波が重畳したケースに おいては，模型下側加速度 $(\mathrm{ACl})$ につては，短周期成 分がのっているものの，模型上側加速度(AC2)では周期 が明確に確認できる.4Hzで加震した地震と津波が重畳 したケースにおいては，8Hzで加振したケースと比較し て，加振周期が長い影響で，越流による影響が大きく出 ている. そのため, 越流方向と同様な方向に働く加速度 (+方向)の継続時間が長く, 逆向きに働く加速度(-)が短い. 加速度の最大值については，加振のみのケースと比較し て0.5〜0.6倍程度小さくなっている.

各実験ケースについて，波圧の最大值と加振周波数の 関係を図-6, 加速度の最大值と加振周波数の関係を図-7 に示す．加振のみの実験について，各地点の波圧と加速 度の最大值を確認すると, 加振周波数が $4 \mathrm{~Hz}$ の時ピーク

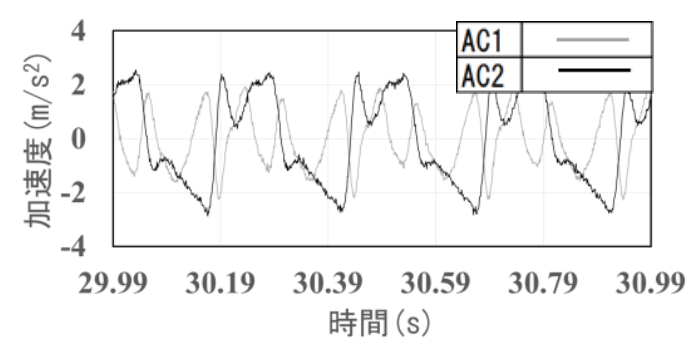

(a) $4 \mathrm{~Hz}, 50 \mathrm{gal}$, 加振のみ

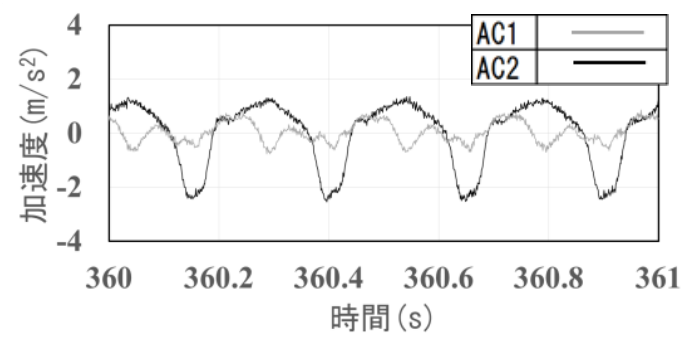

(b) $4 \mathrm{~Hz}, 50 \mathrm{gal}$,加振と越流の重畳

図-5 加振時時刻歴(マウンド変形あり)

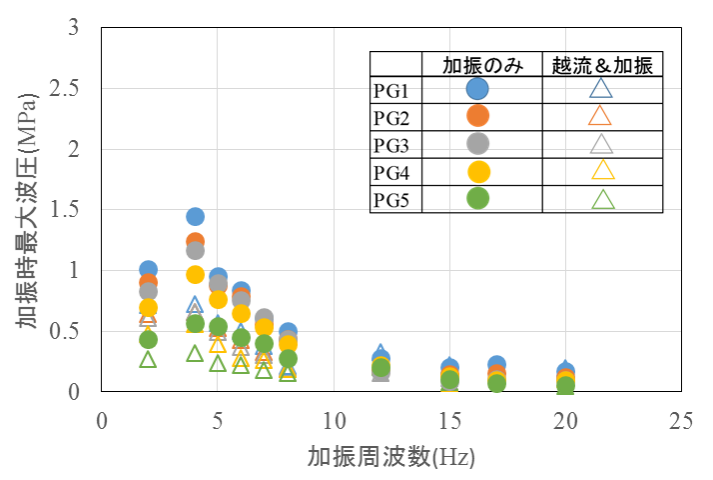

図-6 加振時最大波圧と加振周波数の関係 (マウンド変形あり)
となることが確認できる. 地震と津波が重畳したケース で確認すると，こちらも同様に4Hz付近にピークが確認 できる．加速度の大きさについては，地震と津波重畳時 においては，加振のみの場合と比較して小さいことが明 らかとなった。

\section{(2) 加振周波数の違いにおけるマウンドの変形の有無 の影響}

3. (1)の実験同様，加振強度を $50 \mathrm{gal}$ ，加振周波数を $20 \mathrm{~Hz}$ から2Hzまで変えて実験を行った．マウンドを固めて， 変形を抑制したケースについて，一例として，加振周波 数が $8 \mathrm{~Hz}$ の加速度時刻歴を図-8に，4Hzの加速度時刻歴 を図-9に示す.

8Hzにおける地震のみと，地震と津波を重畳させたケ 一スの，模型上側加速度(AC2)については，加振のみの 場合と比較して，地震と津波が重畳したケースにおいて は，加速度の最大值が 0.3 倍程度と小さく，マウンドが 変形するケース同様, ピークの最大值がはっきりしない 傾向が確認できた。 また，模型下側加速度(AC1)と模型

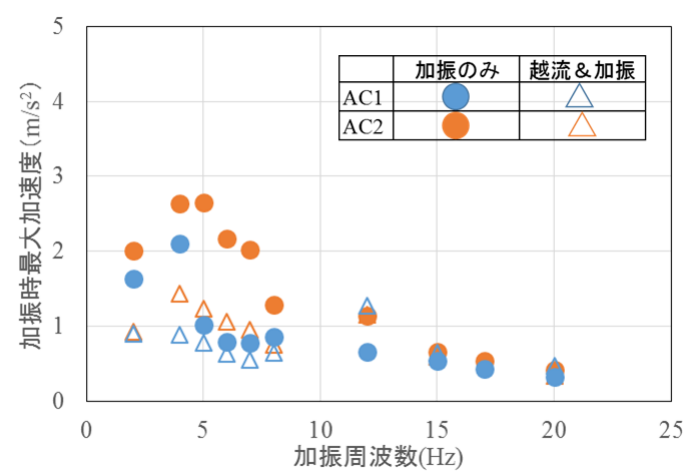

図-7 加振時最大加速度と加振周波数の関係 (マウンド変形あり)

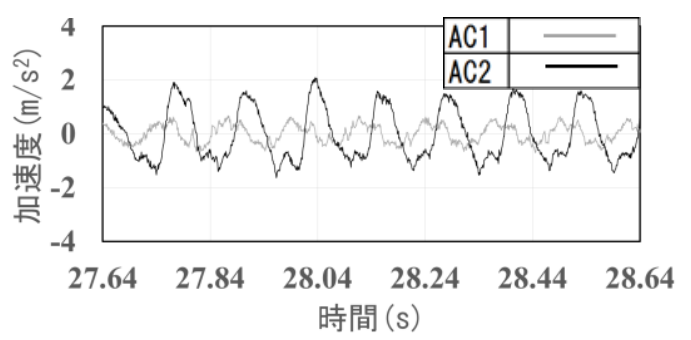

(a) $8 \mathrm{~Hz}, 50 \mathrm{gal}$,加振のみ

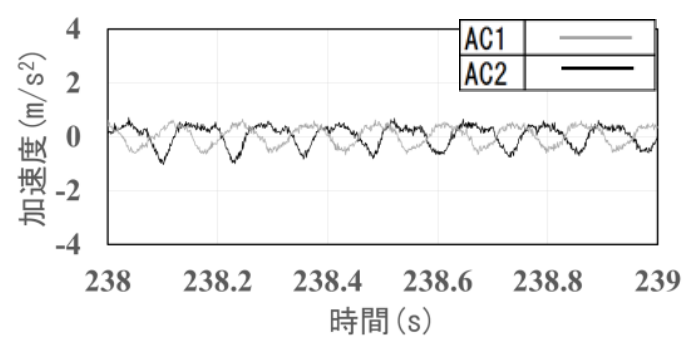

(b) $8 \mathrm{~Hz}, 50 \mathrm{gal}$,加振と越流の重畳

図-8 加振時時刻歴(マウンド変形なし) 
上側加速度(AC2)の位相の差については，マウンドが変 形するケースと比較すると小さいものの，位相差がある ことは確認できる.

次に，4Hzにおける地震のみと，地震と津波を重畳さ せたケースについて確認した。 4Hzにおける模型上側加 速度(AC2)の最大值の出現時刻は，加振のみの場合は模 型下側加速度（AC1）が最大值を示した直後に最大值を 示している，一方で，地震と津波が重畳したケースは， 模型下側加速度(AC1)が低下し始めた際に最大值を示し

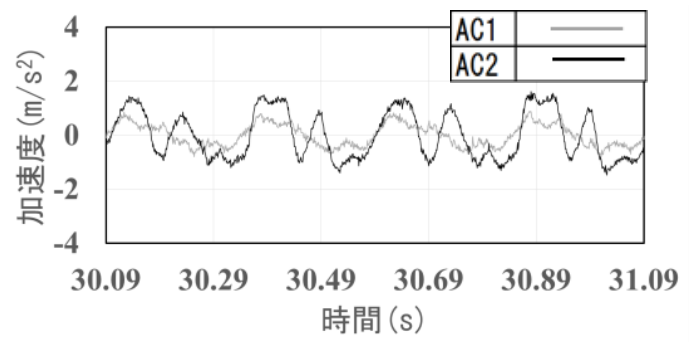

(a) $4 \mathrm{~Hz}, 50 \mathrm{gal}$,加振のみ

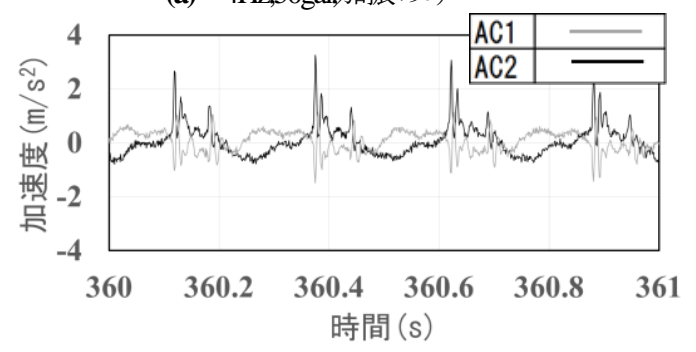

(b) $4 \mathrm{~Hz}, 50 \mathrm{gal}$,加振と越流の重畳

図-9 加振時時刻歴(マウンド変形なし)

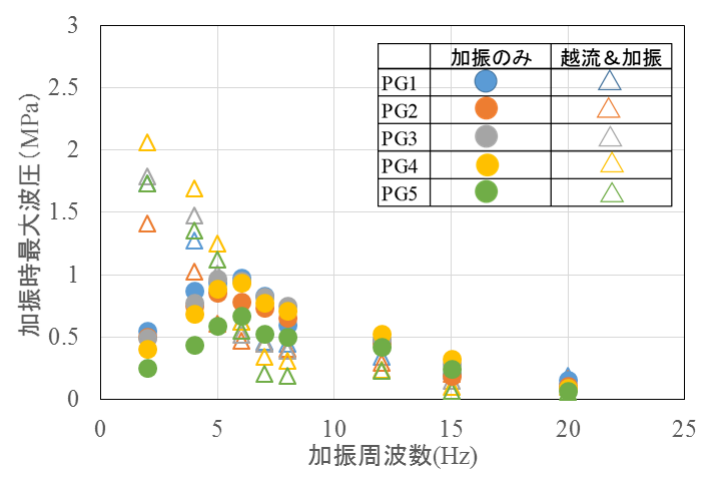

図-10 加振時最大波圧と加振周波数の関係 (マウンド変形なし)

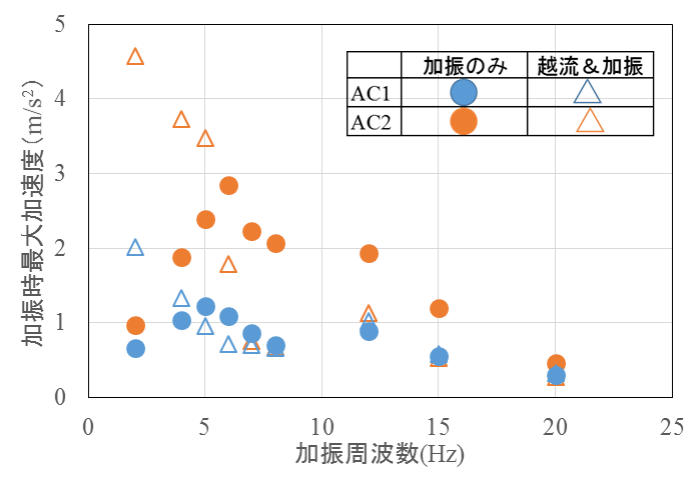

図-11 加振時最大加速度と加振周波数の関係 (マウンド変形なし)
ている。これは，地震と津波が重畳した場合においては， 越流の影響により，模型上側の挙動が制限されているこ とが要因であると考えられる.

各実験ケースについて，波圧の最大值と加振周波数の 関係を図-10, 加速度の最大值と加振周波数の関係を図11に示す. 加振のみの実験について，各地点の波圧と加 速度を確認すると，加振周波数が $5 \mathrm{~Hz}$ から $6 \mathrm{~Hz}$ の時ピー クとなることが確認できる. 次に，地震と津波が重畳し たケースで確認すると，こちらは，マウンドが変形する ケースと異なり，5Hzから6 Hz付近でのピークは確認で きず, 加振周波数が小さいほど, 加振時最大波圧と加振 時最大加速度が増大している傾向が確認できた。

\section{(3) マウンドの変形の有無による地震と津波の重畳が 構造物に与える影響}

地震と津波の重畳がマウンドの変形の有無による構造 物に与える影響の違いについて検討した．検討は，8Hz と $4 \mathrm{~Hz}$ のースについて，マウンド内に設置した加速度 計 $(\mathrm{ACO})$ と模型下側加速度(AC1)および模型上側加速度 (AC2)を比較して行った.

マウンドが変形する場合の8Hzの加速度時刻歴を図-12, 4Hzの加速度時刻歴を図-13に示す. $8 \mathrm{~Hz}$ では，マウンド 加速度 $(\mathrm{AC} 0)$ と模型下側加速度 $(\mathrm{ACl})$ は，ほぼ同様な挙動 を示している．一方で，4Hzでは，マウンド加速度(AC0) の増加開始時刻が模型下側加速度(AC1)の増加開始時刻 と比較して, 若干早い. また, 模型上側加速度(AC2)が 最小となる時に, マウンド加速度(ACO)は最大となって おり，その時の模型下側加速度( $\mathrm{AC} 1)$ はほぼ0である。 ウンドが変形することにより, マウンドと構造物の挙動 に時間差を生み出し，加速度が同じ方向に働く時間が， ずらされているものているものと考えられる.

次に, マウンドが変形しない場合の8Hzの加速度時刻

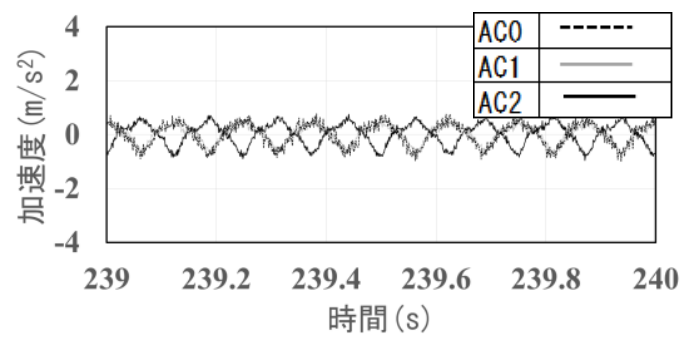

図-12 8Hz,50gal 加振時時刻歴(マウンド変形あり)

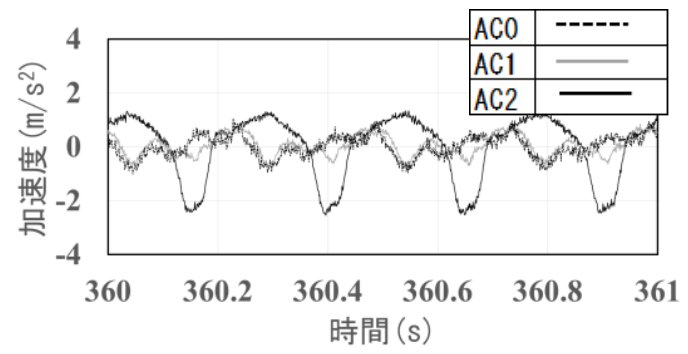

図-13 4Hz,50gal 加振時時刻歴(マウンド変形あり) 
歴を図-14，4Hzの加速度時刻歴を図-15に示す。マウン ドが変形しない場合は，8Hzで地震と津波が重畳したケ ースでは，マウンドが変形するケース同様，マウンド加 速度(AC0) と模型下側加速度(AC1)は，ほぼ同様な挙動を 示している。一方で，4Hzでも，8Hzで地震と津波が重 畳したケース同様，マウンド加速度(AC0)と模型下側加 速度(AC1)は，ほぼ同様な挙動を示している．また，マ ウンドが変形するケースとは異なり, マウンド加速度 $(\mathrm{AC} 0)$ と模型下側加速度(AC1)が越流と同一方向(+)に働く 際に，模型上側加速度(AC2)も同一方向に作用している.

以上のことから，地震と津波の重畳時におけるマウン ドの変形の有無による, 構造物に与える影響の違いは, マウンドが変形する場合は，岸側加振開始時に図-16(a) のように，マウンドに伝わった加速度が構造物に伝わる 時に，マウンドの変形により若干の時間差が発生する. その時間差の影響で模型下側と模型上側の加速度の応答 が異なり，結果，図-16(b)のように，同じ方向に加速度 が作用する時間が短くなり，地震と津波が重畳した際の 構造物に与える加速度の影響を抑制していると考えられ る. 一方で，マウンドが変形しないケースにおいては， 岸側加振開始時に図-17(a)のように，マウンドと構造物 下端においては同様な挙動を示す。そのため, 模型下側 から模型上側へ加速度が伝わる時間差が短くなる. よっ て, 図-17(b)のように, 加速度が全体的に同一方向に働 く時間が長くなり，構造物全体に働く加速度は大きくな る. その結果, 構造物に大きな慣性力が発生し, 残留変 位を蓄積しているものと考えられる.

\section{(4) 低周波数加振における防波堤への影響}

マウンドの変形の有無における低周波数加振時の影響 について，ワイヤー式変位計のデータで確認した。 図一

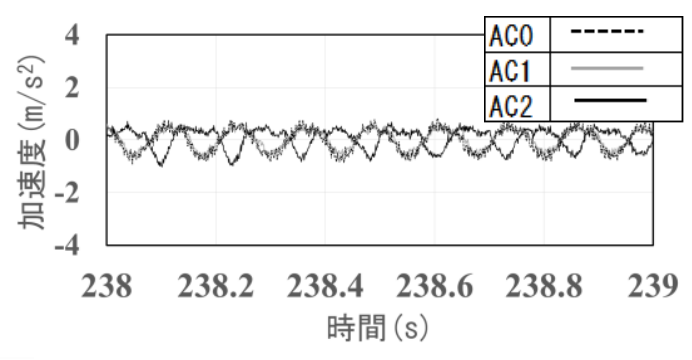

図-14 8Hz,50gal 加振時時刻歴(マウンド変形なし)

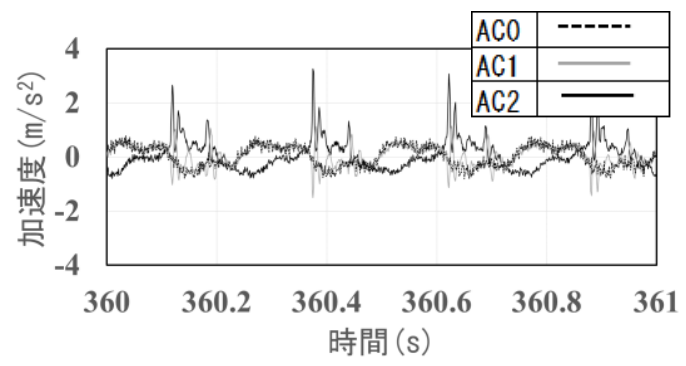

図-15 4Hz,50gal 加振時時刻歴(マウンド変形なし)
18, 図-19に示す.データは $1000 \mathrm{~Hz}$ でサンプリングした 時刻歴のデータを 10 データ毎に移動平均をとったもの である． $2 \mathrm{~Hz}$ で加震し，地震と津波を重畳させたケース について, 模型上側の変位(DT2) と模型下側の変位(DT1) について, マウンドの変形の有無における違いを確認し た. 模型上側と下側の変位の差について着目すると, 図 -18 に示すマウンドが変形する場合は，岸側変位時の最 大変位は，模型下側の変位(DT1)の方が大きい。しかし， 沖側変位時に同様な挙動になり, 大きな残留変位が発生 していない，一方で，図-19 に示すマウンドが変形しな い場合は, 岸側変位時の最大変位の時間が模型上側 (DT2)と模型下側(DT1)で異なる.この結果，沖側変位時

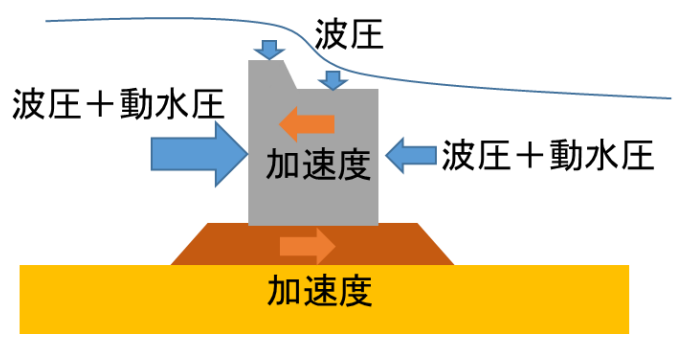

(a)岸側加振開始時

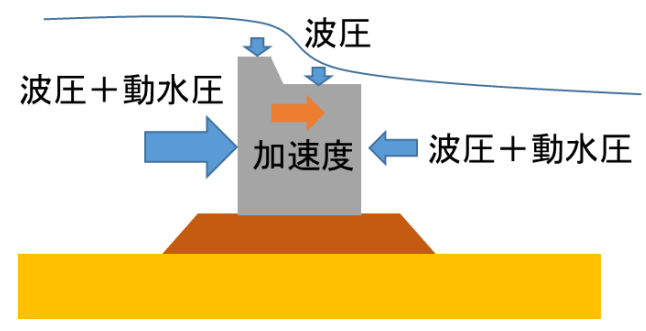

(b)岸側加振後加速度 0 時

図-16 マウンド変形ありの場合の 地震と津波重畳時における構造物の挙動

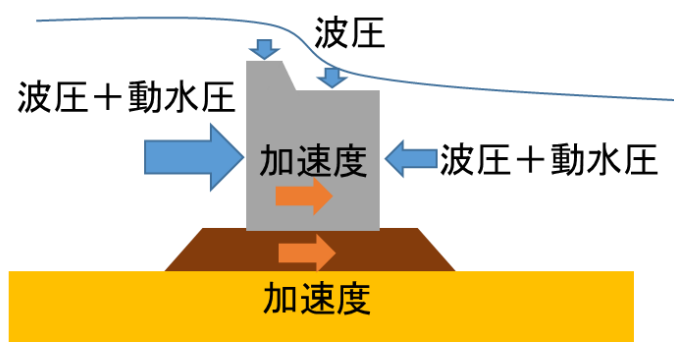

(a)岸側加振開始時

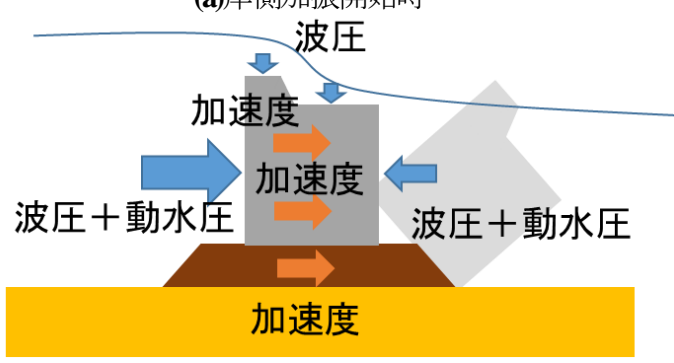

(b)岸側加振後加速度 0 時

図-17 マウンド変形なしの場合の 地震と津波重畳時における構造物の挙動 


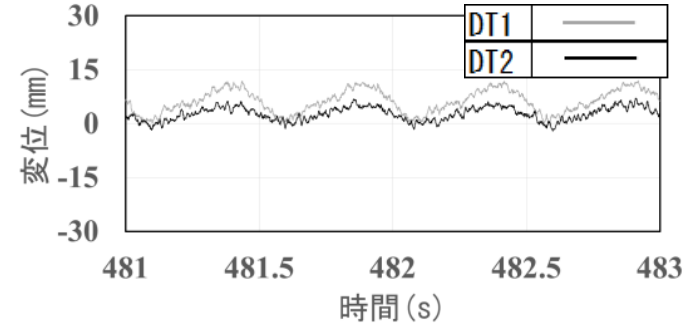

図-18 変位時刻歴(マウンド変形あり,2Hz,50gal)

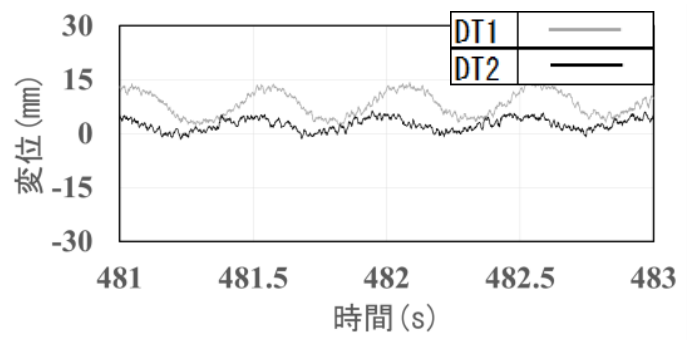

図-19 変位時刻歴(マウンド変形なし, $2 \mathrm{~Hz}, 50 \mathrm{gal}$ )

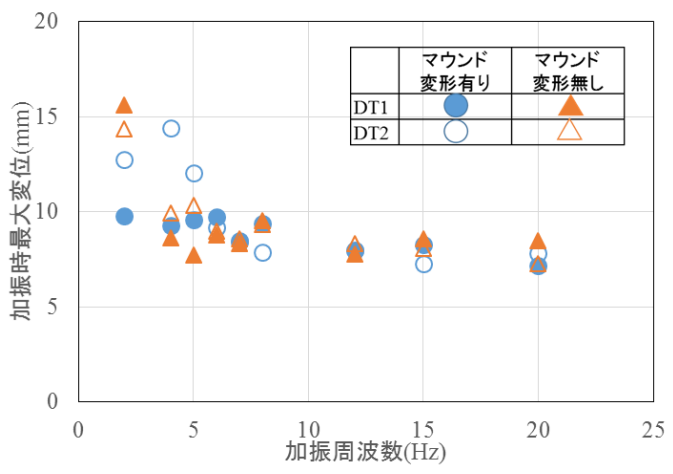

図-20 加振時最大変位と加振周波数の関係

に模型下側の変位(DT1)が戻りきらず，残留変位として 蓄積しているものと考えられる。この現象は，これまで の検討結果から, 加振一波の継続時間が長いほど, 影響 が大きい，そのため，低周波数加振においては，地震と 津波の重畳時においても、変位が増大寸る可能性が大き い事が明らかとなった。

加振時最大変位について加振周波数との関係を図-20 に示す．マウンドの変形が無い場合は，防波堤の変位は
上側(DT2)と下側(DT1)であまり差が無く同様に変位して いる，一方で，マウンドの変形がある場合は，5Hz より 低周波数では，防波堤の上側(DT2) と下側(DT1)での変位 の差が大きくなっている．この結果より，防波堤のマウ ンドは地震と津波重畳時において，ケーソンの加速度を 抑制する効果があり，マウンドが変形しない状態の検討 をすることにより，安全側の評価が可能であることが明 らかとなった。

\section{4. おわりに}

本研究では, 加振周波数に着目し, 地震と津波の重畳 時における影響について検討した。模型の縮尺の影響が あるものの，地震と津波の重畳時においても，地震のみ の場合同様，高周波数領域は変位にあまり影響が無く， 低周波数領域が変位に影響を与えることが明らかとなっ た．また，マウンドの変形の有無により，地震と津波の 重畳時において，構造物に作用する加速度の影響が異な り，重畳時における防波堤に与える影響も異なる。マウ ンドの変形が無い場合においては，低周波数の加振時に 加速度と波圧が増大寸ることが明らかとなった。

\section{参考文献}

1) 有川太郎，佐藤昌治，下迫健一郎，富田孝史，廉慶 善, 丹羽竜也: 津波越流時における混成堤の被災入力 ニズムと腹付工の効果, 港湾空港技術研究所, No.1269, 37p., 2013.

2) 岡田克寬，鈴木高二朗，有川太郎：地震と津波の重畳 時における防波堤への作用力に関する研究，土木学会 論文集 B2(海岸工学), Vol. 72, No. 2, pp. I_1057I_1062.,2016.

3) Westergaard,H.M.:Water Pressure on Dams during Earthquakes, ASCE Transactions No.1835, pp.418-472.,1933.

4）野津厚，井合進，一井康二，沼田淳紀: ケーソン式岸 壁の変形に挙する地震同の振動数成分, レベル 2 地震 に対する土構造物の耐震設計シンポジウムおよびテ キスト, pp.311-318., 2000 .

(2017.3.15 受付)

\section{INFLUENCE OF SHAKING FREQUENCY ON A BREAKEWATER DURING EARTHQUAKE AND TSUNAMI SUPERPOSITION}

\section{Katsuhiro OKADA, Kojiro SUZUKI and Taro ARIKAWA}

In subduction-zone earthquakes, which cause a tsunami, it is considered that the influence of aftershocks may act on a breakwater even when wave-overtopping is taking place. However, it is unclear what effect the superposition of earthquake and tsunami will have on breakwaters. In this study, a large hydroflume capable of reproducing the superposition phenomenon of earthquake and tsunami was used. The study revealed the influence due to frequency difference and the difference depending on the presence or absence of deformation of the mound. 